\title{
Early Intervention in Psychiatry Challenges \& Opportunities
}

\author{
Mamdouh El-Adl \\ Queen University, Kingston, Ontario \\ Canada
}

\section{Introduction}

We may agree that psychiatry has advanced so much within a relatively short life span.

Civilized life is a sign \& reason for good physical and mental health. Herodotus in V Century BC expressed his admiration for the health of Egyptians, saying that they were the healthiest in the world, that "Egyptian are different from other people... they take their meals outside their homes, while they attend to their needs inside". Diodorus Siculus in the first Century BC stated that" the whole manner of life of the Egyptians was so wholesome that it would appear as though it had been arranged according to the rules of a learned physician rather than those of the legislator (Ghaliongui 1983).

Legislation may have an important role to play at some stage of nation's building, but with progress of life, maturity and stability of the population the legislation may be of less importance than previously.

The first mental hospital in the world was built Ephesus of the old Roman empire in the ancient times. In Middle ages there was a mental hospital in Baghdad, Iraq in 705 AD. This was followed by hospitals in Cairo (800 AD0, Damascus 1270 Adand Aleppo in Syria). At the at time, mentally ill patients were being burnt, condemend and punished in Europe (Okasha, 1993)

Psychiatric asylums were landmarks in the history of psychiatric care. Mental Asylums were essentially to help 2 main purposes:

1. Caring for \& protecting the mentally ill people

2. Public protection.

In $18^{\text {th }}$ Century some documentation in the Journal of the Liverpool Psychiatric Club may demonstrate how psychiatry was at that time (Fig 1,2) (Psychiatry in Liverpool,1800).

\subsection{Early attempts to understand mental illness}

In a great step forwards, Benjamin Rush invented a tranquilizer chair as he believed that mental illness is due to irritation of blood vessels in the brain and his treatment method included bleeding, purging, hot \& cold baths and mercury and he invented a tranquilizer chair (Fig4).

This style of thinking is not considered to be scientifically based or evidence based by the rules of our time nowadays but was a very courageous attempt to understand more about mental illness at this relatively early time. With this development the beginning of thinking 
about mental illness, its underlying causes and how to treat started. This may have been an early attempt in the wrong direction but we may agree that lot of discoveries in the field of medicine were not well-planned or evidence -based but started as trial \& error. Most of our recent styles of thinking in the era of evidence-based medicine are relatively new. However there was a believe that Evidence-based medicine, whose philosophical origins extend back to mid-19th century. Earlier, is the conscientious, explicit and judicious use of current best evidence in making decisions about the care of individual patients? The practice of evidence-based medicine means integrating individual clinical expertise with the best available external clinical evidence from systematic research. By individual clinical expertise we mean the proficiency and judgment that we individual clinicians acquire through clinical experience and clinical practice (Sackett, 2006)

Liverpool, $18^{\text {th }}$ century: Dealing with Mentally Ill in Liverpool in The $18^{\text {th }}$ Century

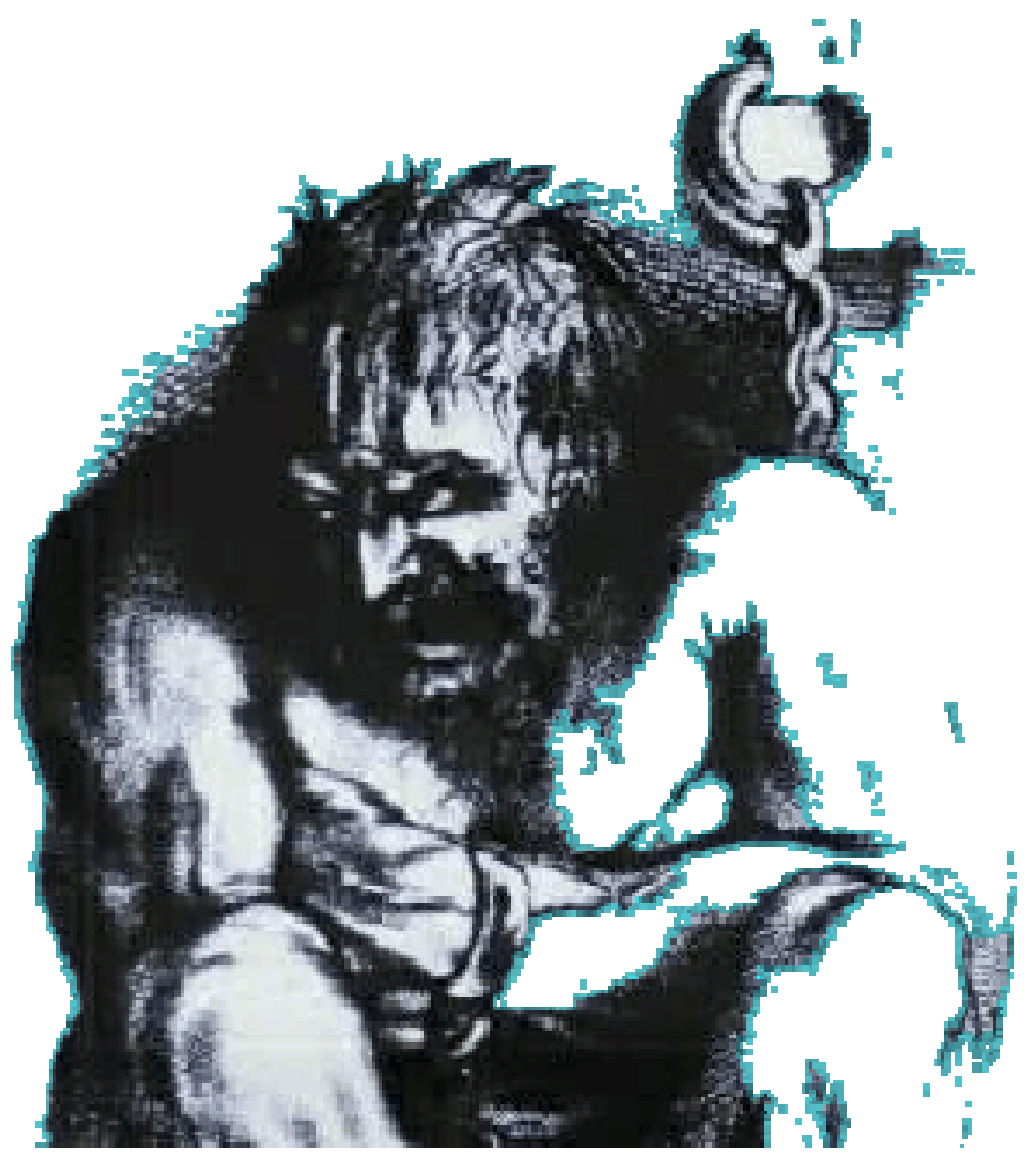

Fig. 1. 


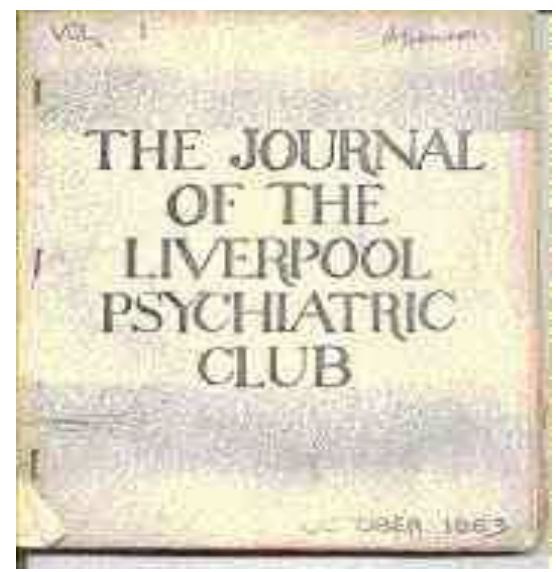

Fig. 2.

\section{Tiverit of}

\section{Psychiatry in Liverpool: 18th Century}
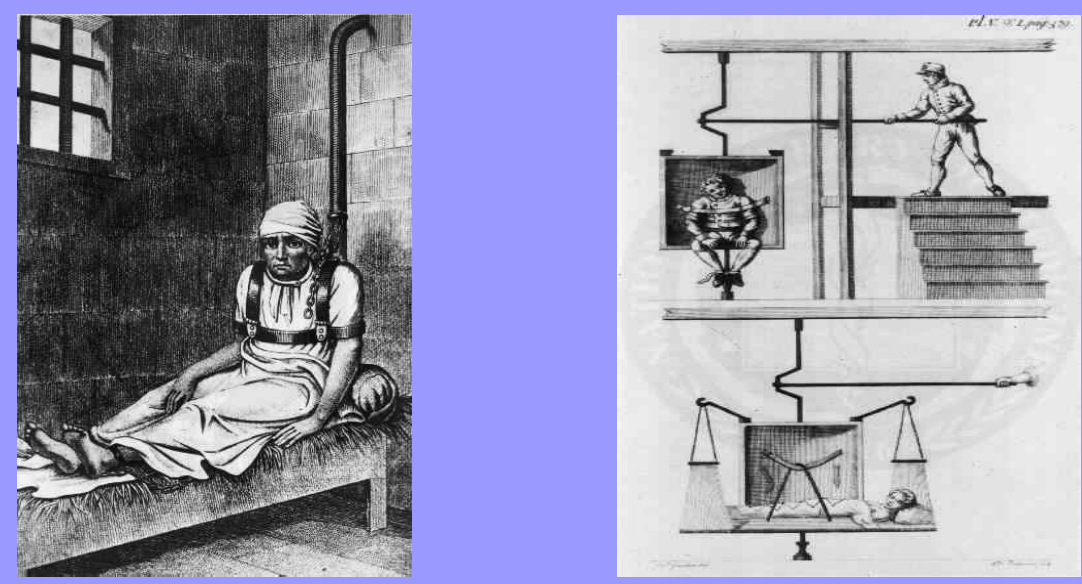

Fig. 3. Care for the mentally ill in Liverpool in the $18^{\text {th }}$ century ${ }^{3}$ 


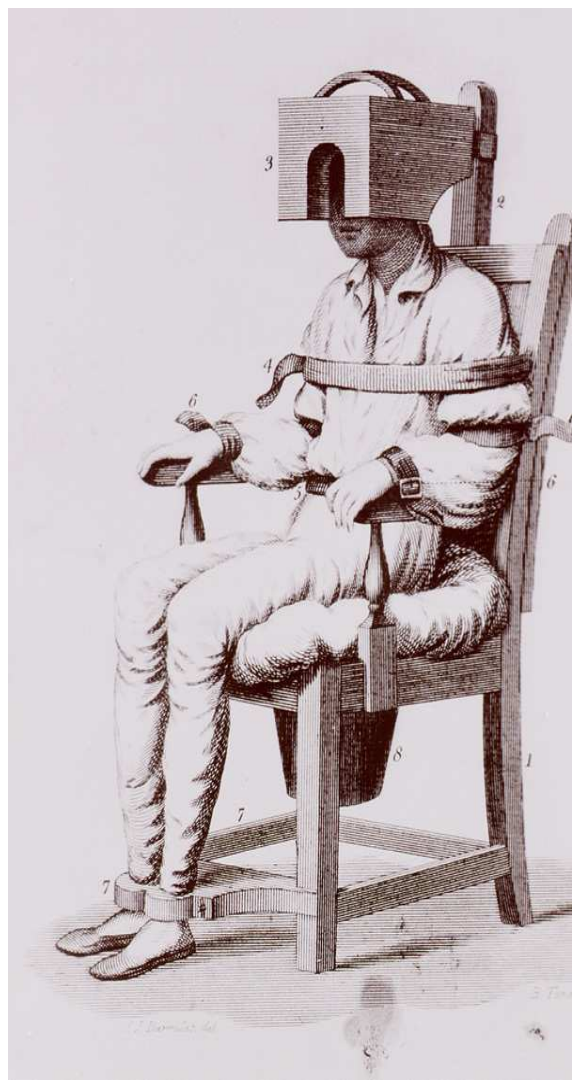

Fig. 4. Tranquilizing chair ${ }^{4}$

However, with further development, Modern psychiatric hospitals evolved from, and eventually replaced the older lunatic asylums.

\subsection{The discovery of chlorpromazine}

The discovery of phenothiazines, the first family of antipsychotic agents has its origin in the development German dye industry, at the end of the 19th century (Graebe, Liebermann, Bernthsen). Up to 1940 they were employed as antiseptics, antihelminthics and antimalarials (Ehrlich, Schulemann, Gilman). Finally, in the context of research on antihistaminic substances in France after World War II (Bovet, Halpern, Ducrot) the chlorpromazine was synthesized at Rhône-Poulenc Laboratories (Charpentier, Courvoisier, Koetschet) in December 1950. Its introduction in anaesthesiology, in the antishock area (lytic cocktails) and "artificial hibernation" techniques, is reviewed (Laborit), and its further psychiatric clinical introduction in 1952, with initial discrepancies between the Parisian Val-de-Grâce (Laborit, Hamon, Paraire) and Sainte-Anne (Delay, Deniker) hospital groups. The first North-American publications on the introduction of chlorpromazine took place in 1954 (Lehmann, Winkelman, Bower). The introduction of chlorpromazine in the USA was more difficult due to their strong psychoanalytic tradition. The consolidation of the neuroleptic 
therapy took place in 1955, thanks to a series of scientific events, which confirmed the antipsychotic efficacy of the chlorpromazine. (Lopez-Munoz et al 2005)

\subsection{Closure of mental asylums \& the beginning of psychiatric units attached to general hospitals}

The development of the modern psychiatric hospital is also the story of the rise of organised, institutional psychiatry. While there were earlier institutions that housed the 'insane' the arrival of institutionalisation as a solution to the problem of madness was very much an event of the nineteenth century. To illustrate this with one regional example, in England at the beginning of the nineteenth century there were, perhaps, a few thousand 'lunatics' housed in a variety of disparate institutions but by 1900 that figure had grown to about 100,000 . That this growth coincided with the growth of madness, later known as psychiatry, as a medical specialism is not coincidental.

The treatment of inmates in early lunatic asylums was sometimes brutal and focused on containment and restraint. With successive waves of reform, development and the introduction of effective evidence-based treatments, modern psychiatric hospitals provide a primary emphasis on treatment, and attempt where possible to help patients control their own lives in the outside world.

Closure of Mental Asylums \& re-integration of people diagnosed with mental illness was claimed by some to have been associated with increased violence in the community. This matter was considered to be an important point to de discussed or even studied. Research did not confirm that release of mentally ill individuals or what was called at that time care in the community was a reason for increased violence and crimes in the community. Some research and published papers addressed this possibility and concluded that mental illness as a single factor may not be responsible for this (Ian Kooyman et al, 2007) and some schoolars called fortigtening and improving mental health legislations to minimise the possibility of loss to care (falling off the net) like Care Programme Approach (CPA) after certain famous cases e.g. happened in the UK e.g. Christopher Clunis and murdering Jonathan Zito. After a big famous investigation they concluded that everybody was to be blamed psychiatrists, social workers, the police, community psychiatric nurses, the Crown Prosecution Service, the probation service, hostel staff, and private sector care workers. (Timmins, 1994).

The use of a combination of psychiatric drugs and Psychotherapy. These treatments can be involuntary under the power of the Mental Health Act which gives the psychiatrists the power to treat even if refused by the patient in many countries. These powers were questioned by the Anti-Psychiatric movement and human rights activists.

\subsection{Community Treatment Order (CTO)}

More recently in countries like UK the Mental Health Act (The Mental Health Act 2005) has been updated giving some powers to enforce treatment in the community "Community Treatment Order" (CTO). However some viewed these as insufficient changes \& some human rights activists viewed these as violations of human rights.

The CTO was considered by many mental health specialists as a good step forward towards ensuring that treatment can access people diagnosed with mental illness and refuse treatment while in the community. However the law has not been able to please everybody, on one hand most mental health professionals perceive it as not enough while human right 
activists view it as a sort of violation of human rights. An important notice that Mental health Professionals had found initially CTO in UK of limited benefit which may reflect more about the understanding \& use of the new Mental Health Act. However, the initial impression of CTO that has been used for sometime in North America especially Ontario Canada seem to be more positive. This may need to be researched and learning from the experience of use across the Atlantic to learn from each other's experience.

\subsection{Mental Health Act}

It is important to remember that there are some varrying number of countries across the world of varying \% that have no Mental Health Act which may be attributed to different factors. These countries may include \% in Africa, Asia \& east meditrranean \& countries in America, (Wikipedia, 2007). With the improved awareness of human rights, the numbers of countries that have a Mental Health Act will hopefully gradually increase to include all patients on the earth. It is hoped that with the continuous efforts of World Psychiatric Association (WPA) and other relevant organisations e.g. WHO more countries will have its own Mental Health Act that would suit its culture and protect patients' rights.

\begin{tabular}{|l|l|l|}
\hline Regions & With legislation & No legislation \\
\hline Africa & $59 \%$ & $41 \%$ \\
\hline The Americas & $73 \%$ & $27 \%$ \\
\hline Eastern Mediterranean & $59 \%$ & $41 \%$ \\
\hline Europe & $96 \%$ & $4 \%$ \\
\hline South-East Asia & $67 \%$ & $33 \%$ \\
\hline Western Pacific & $72 \%$ & $28 \%$ \\
\hline
\end{tabular}

Table 1. \% of countries all over the world regions with or without Mental Health Act

Most psychiatric hospitals now restrict any device that can take photos and aim to protect patients dignity \& human rights.

\subsection{Electroconvulsive therapy (ECT)}

Elelectroconvulsive Therapy (Previously known as Electeric Shock) was first introduced in 1938 by Italian neuropsychiatrists Ugo Celettis and Lucio Bini gained widespread use as a form of treatment in the 1940s and 1950s.

This Treatment Modality has been successfully used as therapy for mental illness for about 80 years. It may have been subject to various improvements but the original principle remains the same. It is considered to a relatively one of the safest \& effective types of therapy. ECT remains the most effective treatment for major depression and a rapidly effective treatment for life- threatening psychiatric conditions, unlike conteporaneous somatic therapies, ECT remains in the active treatment portfolio of modern therapeutics.

It is estimated that approximately 100,000 patients have received ECT annuallyin the USA. A limiting Factor in its use has been the adverse effects of confusion and memory loss associated with associated with the course of treatment. However major innovation in ECT technique to diminish cognitive effects while maintaining benefits. New development in ECT techniques over offer the hope that this form of treatment will find better acceptance among psychiatrists and patients (Kaplan \& Sadock, 2007). 
The developments did not stop at the improvements of hospitals \& hospital care or the community but included advances in drug development. Antipsychotics developed into Atypical Antipsychotics with less side effects and more safety if taken in overdose. However one major problem raised concern which is tendency of the new Antipsychotics to induce weight gain with varriable degrees and sometimes accused of precipitating Diabetes Mellitus.

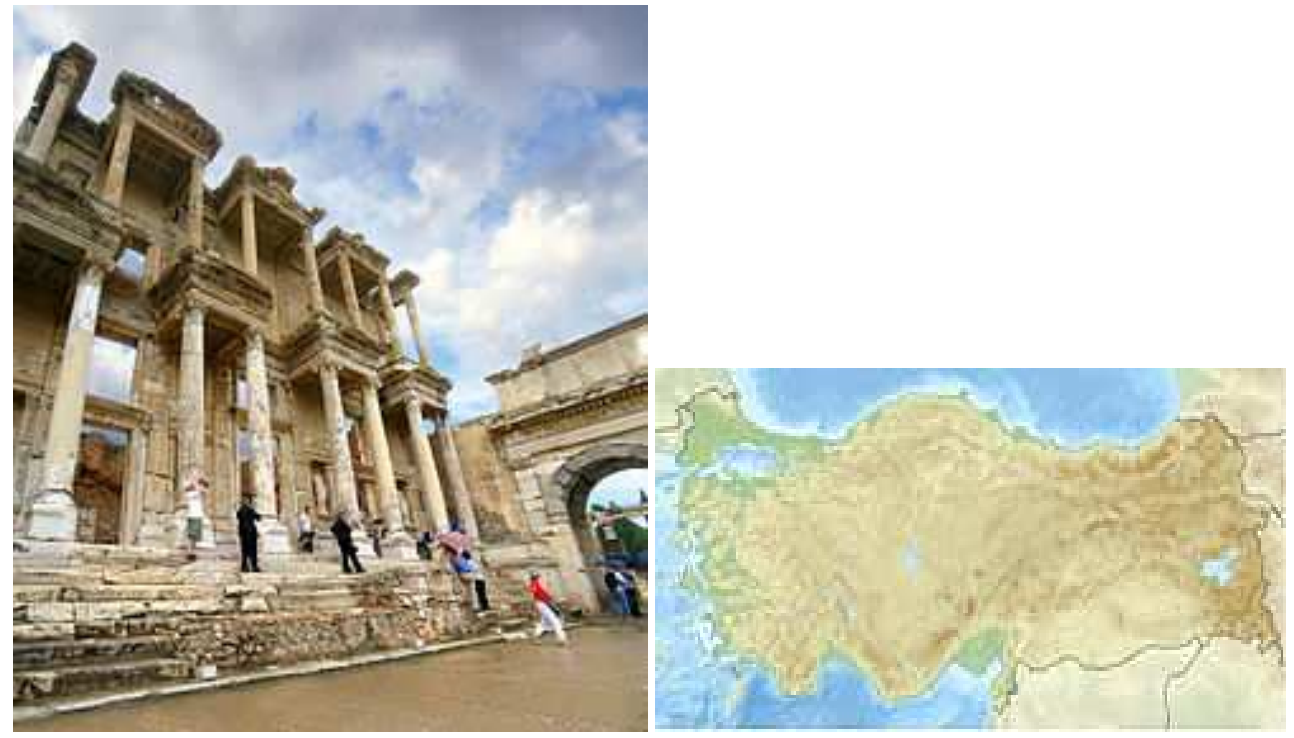

Ephesus: The ancient Roman City (Located in Turkey as per map)

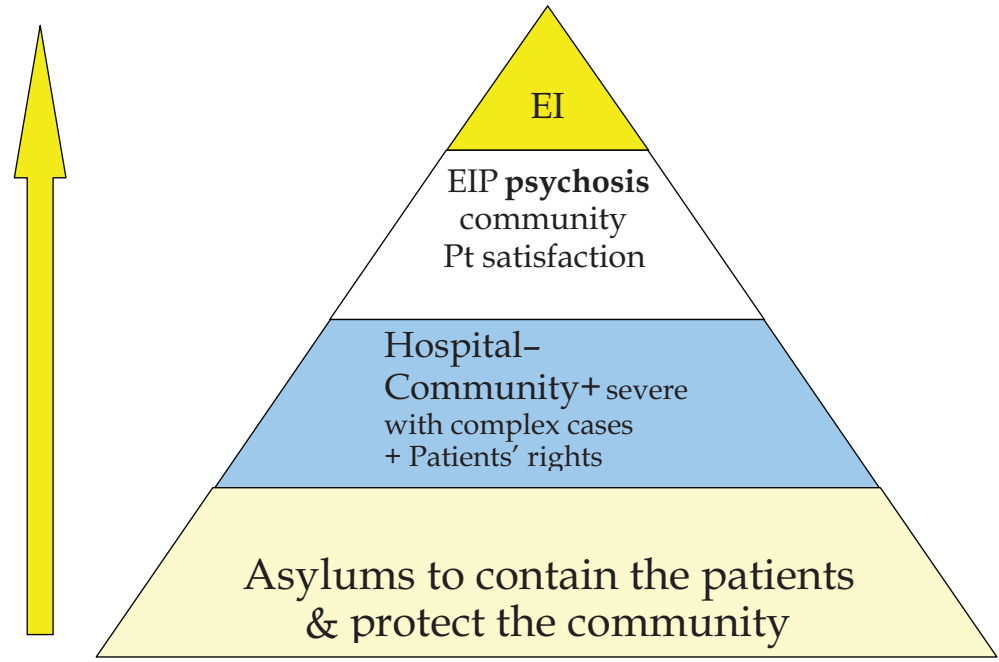

EI: early intervention, EIP: early Intervention in Psychosis,

Fig. 3. History of Psychiatry is developing relatively with a good momentum ${ }^{5}$ 


\section{The importance of community care}

We may have different views about care in the community but there is enough evidence that care in the community has been benefitial. We agree that care in the community is not a replacement for hospital care but compliment it. Unfortunately psychiatric services \& resources are not well developed to the same extent all over the world. The following story may be an example that would be an evidence for the importance of community care. A mother killed her 4 year old daughter and attempted to kill her newly born baby.

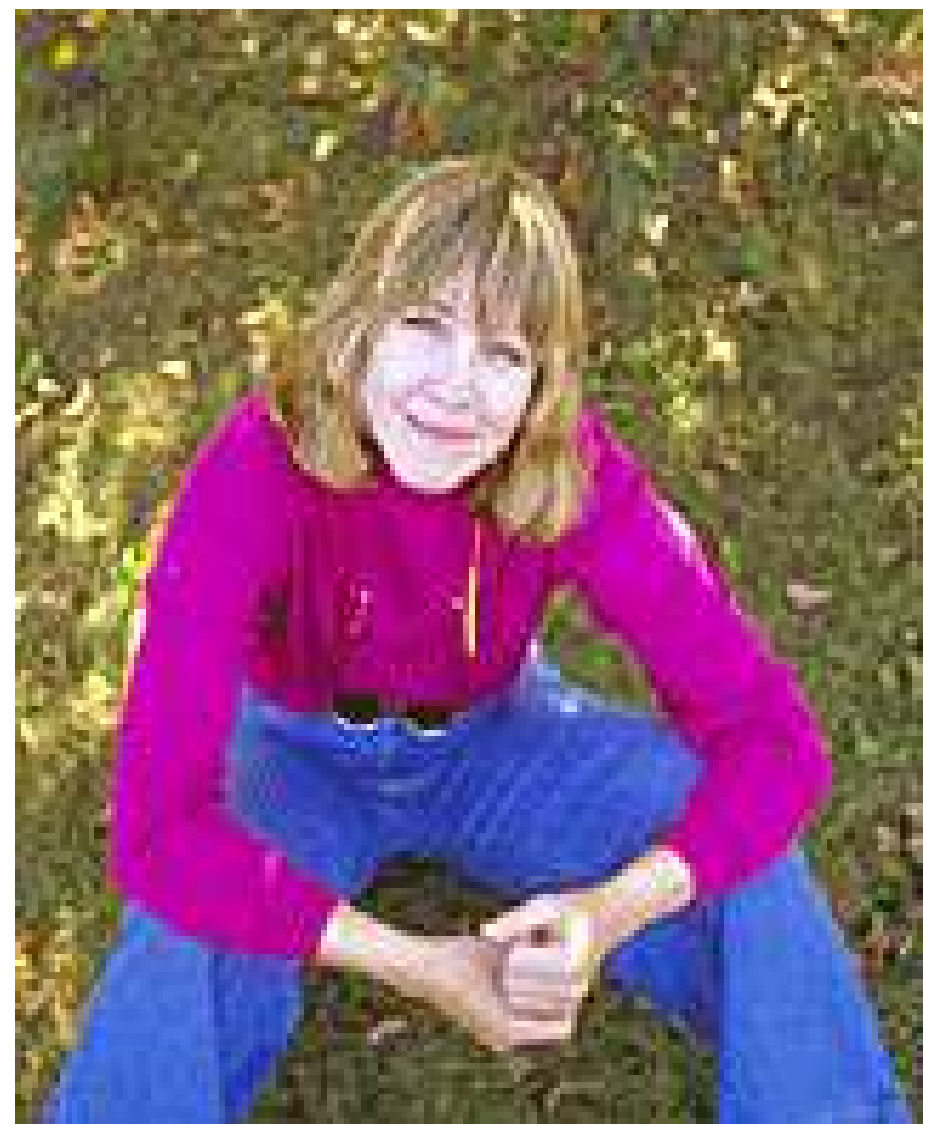

Picture picked up from the net not related to the real incidence for confidentiality.

-23Sunday الصفحة الأولى

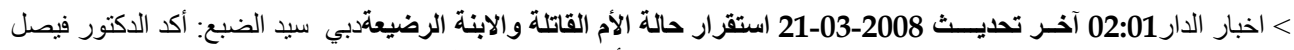

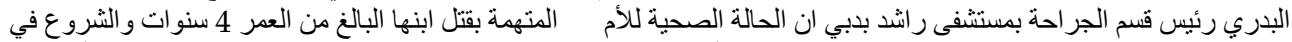

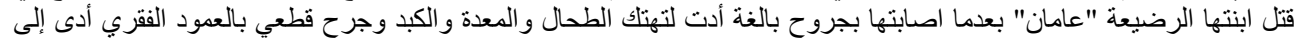

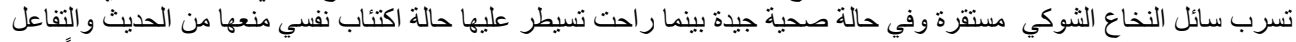

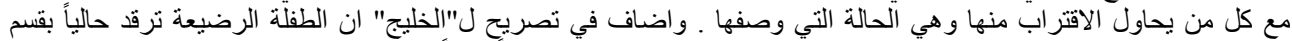

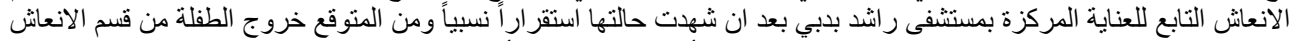

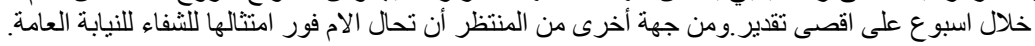


Translation of Arabic News:

A mother killed her 4 year old child, Dr Albadry, Head of Surgical Dept stated that the mother's condition is stable \& her newly born baby is $\mathrm{OK}^{6}$. However this tells us that Psychiatric resources and services are not developed to the same extent all over the world, why? This may be related to local culture, economic factors, available resources, service priorities and service planning.

\section{First episode psychosis studies}

In a UK study addressed GPs experience with first episode psychosis we found out that Stigma remained a strong reason for patients and their families to refuse referral of the individual to see a psychiatrist. This could be imagined in a less developed country but not in a well developed country like UK, however, stigma of mental illness sill a strong reason to deter patients and their family members from first psychiatric referral. This supports Norman Sartorius Who stated that :"Stigma attached to mental illness is the main obstacle to the provision of mental health care 8 This may indicate the need for more work on stigma. We probably need to think of Anti-stigma Programmes not only a campaign.

It was also found that patients with first episode psychosis are less likely to ask for referral to see the psychiatrist but if offered this by their GP they are likely to accept referral. It is very important that we consider public education as a priority in our programmes worldwide. One important point that came out of this study is that GPs feel less inclined to treat psychosis in general especially early psychosis. The study did not address GPs prescribing trends in early psychosis. However GPs appear to be more comfortable treating depression than psychosis. This may be due to training programmes focusing on GPs treating depression to lower suicide rates. Does this indicate that psychosis especially early psychosis will remain the business of psychiatrists and not GPs. More importantly that early diagnosis of psychosis will need to be by specialist care not by primary care. One of the ways that can change the picture is to review GP education and training to give more attention to the area of psychosis. The answer for this question can only be answered with more time.

Interestingly in an Egyptian study on "Factors associated with delayed access to care in a rural Egyptian setting" lack of knowledge, financial factors and stigma were on the top of the list. It is obvious to us that lack of knowledge about mental illness is an important obstacle in developing \& developed countries as well. In a Canadian study, treatment may be delayed if youth, young adults and parents are not aware of the early signs and symptoms of psychosis, the need for early diagnosis and treatment and where and how to get help. This article describes the use of the development of an early psychosis public education program's objectives designed to meet the learning needs of the target population (youth and young adults aged 15-30 years and their parents).

Another finding in the Egyptian Study was that DUP was about one year and this nearly the same in Studies of developed countries, this may be due to small sample studied in Egyptian study or due to presence of high\% of affective psychoses in Egyptian study or this may mean that this is the natural course of the disease regardless the type of intervention or cultural difference i.e. patients with psychosis will arrive relatively late to service.

This may alert us to the need to the importance of working together to develop an international anti-stigma programme that would be culturally compatible worldwide. In the 
case of Egypt \& culturally and economically similar countries, improving public education about mental illness and developing a viable \& effective national health insurance system is likely to play an important role in health promotion in general including mental health.

In his efforts to promote early intervention in psychosis, Professor Patrick McGorie from Australia developed a Clinical staging model Framework for Psychiatric Disorders (fig. 5) that correlates clinical signs with treatment. This may put psychiatrists while handling early psychosis in line with physicians \& surgeons while treating early stages of cancer (Yung \& McGorry, 2007.

It is very interesting and motivating that we can see developments in psychiatry are developing with big steps to catch up with our fellows in other braches of medicine thanks to the efforts of all those who devoted their life to help their patients worldwide.

\section{Clinical Staging Model Framework for Psychotic Disorders (Yung \& McGorry, 2007)}

\begin{tabular}{|c|c|c|c|c|}
\hline stage & Def. & Target Population & Potential intervention & Markers \\
\hline & $\begin{array}{l}-? \text { risk of psychotic disorder } \\
\text { - No symptoms }\end{array}$ & $\begin{array}{l}\text { FD teenage Rs of } \\
\text { probands }\end{array}$ & $\begin{array}{l}\text { ? MH literacy, Family+ } \\
\text { drug edu, Cog Skills train. }\end{array}$ & $\begin{array}{l}\text { SPEmovements, P50, } \\
\text { niacin sensiti. }\end{array}$ \\
\hline & $\begin{array}{l}\text {-mild/nonspecific symptoms } \\
\text { including neurocognitive } \\
\text {-mild functional change or? }\end{array}$ & $\begin{array}{l}\text {-Teenagers screening } \\
\text {-Ref by GPs \& school } \\
\text { counsellors }\end{array}$ & $\begin{array}{l}\text { formal MH literacy, family } \\
\text { psycho-education, active } \\
\text { drug misuse?, formal CBT }\end{array}$ & $\begin{array}{l}\text { Trait \& state } \\
\text { candidates where } \\
\text { feasible }\end{array}$ \\
\hline & $\begin{array}{l}\text { Ultra high risk: moderate but } \\
\text { subthreshold symptoms e.g. } \\
\text { neurocognitive changes \& } \\
\text { function. changes to caseneness }\end{array}$ & $\begin{array}{l}\text { Ref by GP, Education, } \\
\text { Welfare agencies, ER }\end{array}$ & As $1 \mathrm{a}$ & $\begin{array}{l}\text { Niacin sensitivity, } \\
\text { folate status, MRI, } \\
\text { HTPA axis } \\
\text { dysregulation }\end{array}$ \\
\hline 2 & $\begin{array}{l}\text { FEPsychosis, full threshold } \\
\text { disorder, mod.-severe symptoms, } \\
\text { neurocog. Deficits, functional ?, } \\
\text { (GAF: } 30-50 \text { ) }\end{array}$ & $\begin{array}{l}\text { Ref by GP, Education, } \\
\text { ER, Specialist care } \\
\text { agencies, drug \& } \\
\text { alcohol services }\end{array}$ & $\begin{array}{l}\text { As } 1+ \\
\text { Atypical antipsychotic } \\
\text { Vocational rehabilitation }\end{array}$ & $\begin{array}{l}\text { State \& trait markers } \\
\& \text { progression }\end{array}$ \\
\hline & $\begin{array}{l}\text { Incomplete remission from FEP } \\
\text { Could be linked to stage } 4\end{array}$ & $\begin{array}{l}\text { Primary \& specialist } \\
\text { services }\end{array}$ & $\begin{array}{l}\text { As } 2+\text { focus on medical \& } \\
\text { psychosocial } \rightarrow \text { full Remiss }\end{array}$ & As 2 \\
\hline $3 b$ & $\begin{array}{l}\text { Relapse/recurrence of psychosis, } \\
\text { stabilises with treatment at a GAF } \\
\text { level }\end{array}$ & As $3 a$ & $\begin{array}{l}\text { As } 3 a+\text { emphasis on } \\
\text { relapse prevention \& early } \\
\text { warning signs strategies }\end{array}$ & As 2 \\
\hline $3 c$ & $\begin{array}{l}\text { Multiple relapses, impact of illness } \\
\text { is objectively present. }\end{array}$ & Specialist service & $\begin{array}{l}\text { As } 3 b+\text { emphasis on long } \\
\text { term stabilisation }\end{array}$ & As 2 \\
\hline 4 & $\begin{array}{l}\text { Severe persistent or unremitting } \\
\text { judged on symptoms, } \\
\text { neurocognition \&disability criteria }\end{array}$ & As $3 c$ & $\begin{array}{l}\text { As } 3 c+\text { emphasis on } \\
\text { Clozapine \& Social } \\
\text { participation }\end{array}$ & As 2 \\
\hline
\end{tabular}

Fig. 5. Clinical Staging Model Framework for Psychotic Disorders (Yung \& McGorry, 2007)

\subsection{Challenges}

1. Evidence based practice: further integration of research into clinical practice \& Service planning is not always cheap but benefits are likely to outweigh costs.

2. Early intervention needs to be more inclusive e.g. Mood Disorders, Eating Disorders, ....etc..

3. A preventive approach is necessary especially in Child Psychiatry

4. Stigma: we need Anti-stigma Programmes not only campaigns. 
5. Third world countries patients: should not be forgotten.

\subsection{Opportunities}

1. Bringing Psychiatry more into medicine.

2. Further integration of Hospital care into Community programs.

3. Strengthening the Interface between secondary and primary care.

The Challenges are numerous and opportunities can be increased but we need to remain determined to make the future of Psychiatry \& psychiatric patients a better future worldwide.

One important question that may need to be understood: do we expect that early intervention in psychiatry is going to be cheaper in cost compare to traditional care. The careful understanding and studying of this matter may tell us different answer that may disappoint some of us. The same may apply to working on evidence-based, is it likely to be cheaper? The experts believe that early intervention in psychiatry or working on evidencebased rules are likely to be associated with increased financial cost rather than reducing the cost. However, it may be important to do the appropriate practice with more cost than to practice inappropriately.

\section{References}

Crisp, pp373 - 375, published by the Royal Society of Medicine press ltd. Liverpool Psychiatric Club website accessed on 06.2011 www.uphs.upenn.edu/paharc/features/brush.html, accessed on 25.06.2011

EL-Adl M (2009) Presented at Queen University, Kingston, Ontario, Canada under the title: Early Intervention in Psychiatry

EL-Adl M, Elmahdy, M, Anis M (2008) First episode psychosis: Factors associated with delayed access to care in a rural Egyptian setting Vol 5, No 4, October ISSN 1749 3676

EL-Adl, M; Burke, J \& Little K (2009) First-episode psychosis: primary care experience and implications for service development Psychiatric Bulletin

Kaplan, BJ \& Sadock, VA (2007) Brain Stimulation in synopsis of Psychiatry, 10th edition, ippincott Williams \& Wilkins, pp:1118 - 1125

Ephesus- Wikipedia, the free encyclopedia, accessed on 03.08.11

Khaleej Times Home - ubai News, UAE News, Gulf, News, Abu Dhabi, accessed on 25.0611, 2009 v. 33, p. 165-168. [Abstract] [Full Text] [PDF]

Koyman I, Kimberlei D, Harvey S \& Walsh E (2007), Br J Psychiatry, 191, s29 -39, doi 10 1192/ bjp 191.50.s29

Lopez- Junoz F, Alamao C, Cuneca C, shenn, Clervoy P, Rubio G (2005) History of discovery \& clinical introduction of Chloroproimazine. Annals of Clinical Psychiatry,17 (3) $113-35$

Ghalliongi (1983)Magic and Medical Science in Ancieny Egypt, The Physicians of Pharonic Egypt. Al AhramCentrefor Scientific Translation, Cairo.

Timmins, N (1994) Christopher Clunis Report: Schizophrenic made 'series of violent attacks', The Independent.

Okasha A (1993) Psychiatry in Egypt. Psychiatric Bulletin 17 :548-551. 
Psychiatry in Liverpool, $18^{\text {th }}$ century PSYCHIATRY ...Journal of the Liverpool Psychiatric Club

Sartorius N (2004) The world Psychiatric Association global programme against stigma and discrimination because of schizophrenia, in Every family in the Land "revised edition \& reprinted 2005", edited by Arthur

Sacett D (1997) Evidence based medicine. Seminars of perinatology, vol -1, issue 1, February 1997, page 3 - 5

Yeo, M, Berzins S \& Addington, D (2007) Development of an early psychosis public education program using the PRECEDE-PROCEED model. In Advance Access publication 27 October 2006Vol.22 no.5 2007, Pages 639-647 accessed on 25.06.2011.

Yung, A \& McGORRY , P (2007) Prediction of psychosis: setting the stage. The British Journal of Psychiatry 2007 v. 191, p. s1-s8. [Abstract] [Full Text] [PDF]

Porter, Roy (2006). Madmen: A Social History of Madhouses, Mad-Doctors \& Lunatics. Tempus: p. 14

Wikipedia. History of asylums, accessed on 6.7.2011 


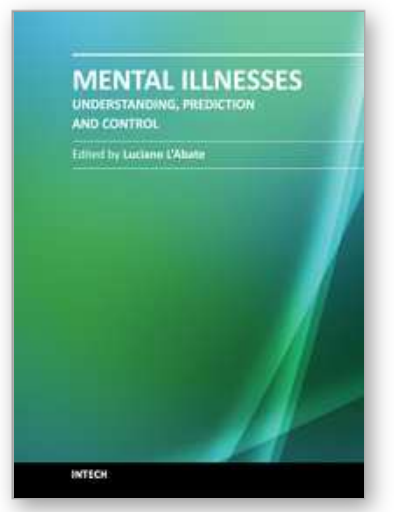

\author{
Mental IIInesses - Understanding, Prediction and Control \\ Edited by Prof. Luciano LAbate
}

ISBN 978-953-307-662-1

Hard cover, 458 pages

Publisher InTech

Published online 05, January, 2012

Published in print edition January, 2012

In the book "Mental Illnesses - Understanding, Prediction and Control" attention is devoted to the many background factors that are present in understanding public attitudes, immigration, stigma, and competencies surrounding mental illness. Various etiological and pathogenic factors, starting with adhesion molecules at one level and ending with abuse and maltreatment in childhood and youth at another level that are related to mental illness, include personality disorders that sit between mental health and illness. If we really understand the nature of mental illness then we should be able to not only predict but perhaps even to control it irrespective of the type of mental illness in question but also the degree of severity of the illness in order to allow us to predict their long-term outcome and begin to reduce its influence and costs to society. How can we integrate theory, research evidence, and specific ways to deal with mental illness? An attempt will be made in the last conclusive chapter of this volume.

\title{
How to reference
}

In order to correctly reference this scholarly work, feel free to copy and paste the following:

Mamdouh El-Adl (2012). Early Intervention in Psychiatry Challenges \& Opportunities, Mental Illnesses Understanding, Prediction and Control, Prof. Luciano LAbate (Ed.), ISBN: 978-953-307-662-1, InTech, Available from: http://www.intechopen.com/books/mental-illnesses-understanding-prediction-and-control/earlyintervention-in-psychiatry-challenges-opportunities

\section{INTECH}

open science | open minds

\section{InTech Europe}

University Campus STeP Ri

Slavka Krautzeka 83/A

51000 Rijeka, Croatia

Phone: +385 (51) 770447

Fax: +385 (51) 686166

www.intechopen.com

\section{InTech China}

Unit 405, Office Block, Hotel Equatorial Shanghai

No.65, Yan An Road (West), Shanghai, 200040, China

中国上海市延安西路65号上海国际贵都大饭店办公楼 405 单元

Phone: +86-21-62489820

Fax: $+86-21-62489821$ 
(C) 2012 The Author(s). Licensee IntechOpen. This is an open access article distributed under the terms of the Creative Commons Attribution 3.0 License, which permits unrestricted use, distribution, and reproduction in any medium, provided the original work is properly cited. 